\title{
Asymmetric organocatalytic Michael addition of cyclopentane-1,2-dione to alkylidene oxindole
}

\author{
Estelle Silm, Ivar Järving and Tõnis Kanger
}

\author{
Full Research Paper \\ Address: \\ Department of Chemistry and Biotechnology, Tallinn University of \\ Technology, Akadeemia tee 15, 12618 Tallinn, Estonia \\ Email: \\ Tõnis Kanger* - tonis.kanger@taltech.ee \\ * Corresponding author \\ Keywords: \\ cyclopentane-1,2-dione; enantioselective catalysis; Michael addition; \\ organocatalysis; squaramide
}

Beilstein J. Org. Chem. 2022, 18, 167-173. https://doi.org/10.3762/bjoc.18.18

Received: 30 November 2021

Accepted: 26 January 2022

Published: 03 February 2022

Associate Editor: P. Schreiner

(C) 2022 Silm et al.; licensee Beilstein-Institut.

License and terms: see end of document.

\begin{abstract}
An asymmetric Michael reaction between cyclopentane-1,2-dione and alkylidene oxindole was studied in the presence of a multifunctional squaramide catalyst. Michael adducts were obtained in high enantioselectivities and in moderate diastereoselectivities.
\end{abstract}

\section{Introduction}

Diketones are generally very versatile starting materials in organic synthesis [1,2]. Specifically, due to their keto-enol tautomerism and high reactivity, diketones are excellent precursors for different pharmaceuticals [3]. Cyclic 1,3-diketones have been widely exploited to access enantiomerically enriched scaffolds with increased molecular complexity. There are many examples of the organocatalytic synthesis of fused cycles starting from the cyclohexane-1,3-dione. For example, Rueping et al. demonstrated that the cyclohexane-1,3-dione undergoes a cascade reaction with $\alpha, \beta$-unsaturated aldehydes [4] and they later employed the method to synthesise indoloquinolizidines [5]. Moreover, six-membered and five-membered cyclic 1,3-diketones have been investigated in reactions with acetates of nitroalkenes [6], cyanoacrylates and benzylidene malononitriles [7], ortho-hydroxy-benzhydryl alcohols [8], $\alpha, \beta$-unsatu- rated pyrazolamides [9] and, 2-oxobut-3-enoates [10]. A 1,2dicarbonyl moiety is also an important structural fragment present in various natural products and biologically active compounds [11]. 1,2-Diketones have been used for the synthesis of photosensitive polymers [12] and substituted imidazoles [13,14] and have been used in carbohydrate chemistry [15]. Cyclic sixmembered 1,2-diketones have been shown to react with benzylidene malononitriles [7,16], $\beta$-nitrostyrenes [17] and substituted propionaldehydes [18]. For a while, there were no examples related to cyclopentane-1,2-dione (CPD). In 2004, the first instance of using CPD as a precursor for high value-added fine chemicals such as a homocitric acid lactone was published by our group [19]. Since then we have developed synthetic pathways for lycoperdic acid [20] and nucleoside analogues [21] starting from CPD. The organocatalytic methods for the synthe- 
sis of substituted cyclopentane diones were uninvestigated until 2014 when we showed that CPD undergoes a Michael addition with nitrostyrenes [22]. Subsequently, different cascade reactions for CPD have been developed: with highly reactive $(E)-2-$ oxobut-3-enoates [23], $\alpha, \beta$-unsaturated aldehydes [24] and alkylidene malonates [25].

Herein, we report the results of an asymmetric organocatalytic Michael addition of CPD to alkylidene oxindoles.

\section{Results and Discussion}

Chiral multifunctional thioureas [26,27] and squaramides [28] are extensively used as catalysts in asymmetric Michael additions. We believed that a bifunctional hydrogen-bonding catalyst would activate both CPD via a tertiary amino group of a quinuclidine moiety acting as a base via anion-binding, and an oxindole through the squaramide or thiourea moieties of the catalyst as hydrogen bond donors (Figure 1) [29-32].

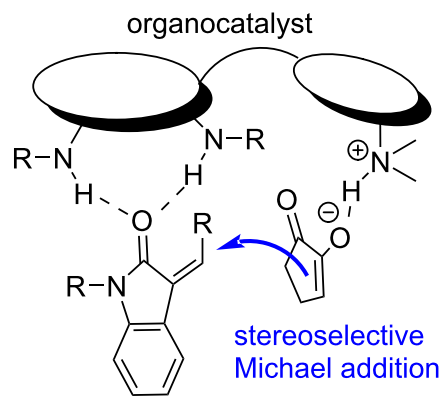

Figure 1: Model of the catalyst action.
Therefore, squaramide and thiourea catalysts were screened in a model reaction between CPD 1 and Boc-protected benzylidene oxindole 2a at room temperature in the presence of $10 \mathrm{~mol} \%$ of catalyst (Figure 2).

First, the quinidine-derived squaramide $\mathbf{A}$ was used and the desired product was obtained as a mixture of chromatographically inseparable diastereoisomers in 53\% yield but in low enantiomeric excess for both diastereomers (Table 1, entry 1). With the quinine-derived thiourea $\mathbf{B}$, the reaction was slow and the yield was very low, $12 \%$ (Table 1 , entry 2 ). For that reason, we focused on the screening of squaramides. Squaramides were found to be more selective catalysts than thioureas. When squaramide $\mathbf{C}$ was used as a catalyst, the product was isolated in $80 \% / 87 \%$ ee (major/minor diastereoisomer) (Table 1 , entry 3 ). The enantioselectivity was even higher with the cinchoninederived squaramide D, 85\%/92\% (major/minor) (Table 1, entry 4). To further optimise the reaction, we screened different solvents (apolar, polar aprotic, and chlorinated solvents) (Table 1, entries 5-7). According to the obtained results chloroform was clearly superior to other solvents. Previously the isolated yield of the product had been moderate and to increase the yield the substrate concentration was varied. A substantial excess of CPD (five equivalents) led to a very slow reaction and a decrease in enantioselectivity (Table 1 , entry 8 ). It was assumed that the binding between CPD and the catalyst was stronger than the binding between the substituted oxindole and the squaramide decreasing the effective concentration of the catalyst. Taking this into consideration, 2 equiv of substituted oxindole was used and the reaction proceeded smoothly in $2 \mathrm{~h}$ in high enantioselectivity $(90 \% / 94 \%$ ee), in high yield $(74 \%)$ but in moderate<smiles>CC[C@H]1CN2CC[C@@H]1C[C@H]2[C@H](Nc1c(Nc2cc(C(F)(F)F)cc(C(F)(F)F)c2)c(=O)c1=O)c1ccnc2ccc(OC)cc12</smiles><smiles>[B]CC1CN2CC[C@H]1C[C@H]2C(NC(=S)Nc1cc(C(F)(F)F)cc(C(F)(F)F)c1)c1ccnc2ccc(OC)cc12</smiles><smiles>C=C[C@H]1C[C@@H]2CC[C@H]1N2[C@H](Nc1c(NCc2cc(C(F)(F)F)cc(C(F)(F)F)c2)c(=O)c1=O)c1ccnc2ccc(OC)cc12</smiles><smiles>C=C[C@H]1CN2CC[C@H]1C[C@H]2[C@H](Nc1c(NCc2cc(C(F)(F)F)cc(C(F)(F)F)c2)c(=O)c1=O)c1ccnc2ccccc12</smiles> 
Table 1: Screening conditions for the reaction ${ }^{\mathrm{a}}$.

\begin{tabular}{|c|c|c|c|c|c|c|c|}
\hline Entry & Catalyst & Solvent & Temp. & Time & Yield $^{b}$ & $\mathrm{dr}$ & ee\%c (major/minor) \\
\hline 1 & A & chloroform & rt & $2 \mathrm{~h}$ & $53 \%$ & $3: 1$ & $43 / 27$ \\
\hline 2 & B & chloroform & rt & 6 days & $12 \%$ & $3.8: 1$ & $-57 /-67$ \\
\hline 3 & C & chloroform & $\mathrm{rt}$ & $7 \mathrm{~h}$ & $59 \%$ & $2.4: 1$ & $80 / 87$ \\
\hline 4 & D & chloroform & rt & $2.5 \mathrm{~h}$ & $58 \%$ & $3: 1$ & $85 / 92$ \\
\hline $5^{d}$ & D & toluene & rt & 2 days & $54 \%$ & $2.5: 1$ & $77 / 81$ \\
\hline $6^{d}$ & D & THF & rt & 2 days & $44 \%$ & $2.6: 1$ & $68 / 74$ \\
\hline $7^{d}$ & D & $\mathrm{DCM}$ & $\mathrm{rt}$ & 1 day & $51 \%$ & $2.5: 1$ & $83 / 83$ \\
\hline $8^{e}$ & D & chloroform & $\mathrm{rt}$ & 12 days & $59 \%$ & $2.2: 1$ & $71 / 87$ \\
\hline $9^{f}$ & D & chloroform & $\mathrm{rt}$ & $2 \mathrm{~h}$ & $74 \%$ & $2.6: 1$ & $90 / 94$ \\
\hline $10^{f}$ & D & chloroform & $0^{\circ} \mathrm{C}$ & $23 \mathrm{~h}$ & $75 \%$ & $2.7: 1$ & $90 / 97$ \\
\hline
\end{tabular}

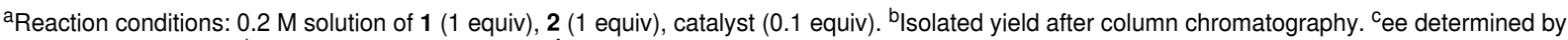
chiral HPLC analysis. ${ }^{d} 1.5$ equiv of $1 ;{ }^{5} 5$ equiv of $1 ;{ }^{\mathrm{f}} 2$ equiv of $2 \mathbf{2 a}$.

diastereoselectivity (Table 1, entry 9). Next, we looked onto the effect of lower temperature on the reaction. At $0{ }^{\circ} \mathrm{C}$ the reaction was approximately 10 times slower and only the ee of the minor diastereoisomer increased by $3 \%$ (Table 1 , entry 10 ), so there was no justification for carrying out the reaction at a lower temperature because of the longer time needed.

Next, we screened different protecting groups for the oxindole. Previously, Boc-protected oxindole 2a gave us the product in $75 \%$ yield, in dr 2.6:1 and in ee $90 \% / 94 \%$ (Scheme $1,3 \mathbf{3 a}$ ). With a Cbz-protecting group the enantioselectivity decreased to $82 \% /$ $88 \%$ (Scheme $1, \mathbf{3 b}$ ). The use of a sterically more demanding Fmoc-protecting group decreased the ee values even more for the minor diastereoisomer (Scheme 1, 3c). Surprisingly, with benzyl-protected oxindole, the reaction did not proceed (Scheme 1, 3d), which implies that the carbonyl group of the carbamate moiety in the $\mathrm{N}$-protecting group and electron-withdrawing properties of the protection groups are essential for coordination with the catalyst and for the reactivity of the Michael acceptor. Using a tosyl-protected oxindole the reaction was sluggish, the yield was low and the enantioselectivity could not be determined (Scheme 1, 3e). These experiments revealed that the best results were achieved in chloroform at room temperature with catalyst $\mathbf{D}$, using 1 equiv of diketone and 2 equiv of $N$-Boc-substituted oxindole $\mathbf{2 a}$.
Under optimised conditions, the substrate scope of the reaction was examined by using various substituted oxindoles with an $E$-configuration of the double bond. The results are presented in Scheme 2. Both electron-withdrawing (Scheme 2, 3f-h) and electron-donating groups (Scheme 2, 3m,n) at the phenyl ring of the benzylidene moiety were tolerated. The position of the halide at the aromatic ring did not have a major effect on the yield or the enantioselectivity. Ortho-, meta- and para-chlorophenyl-substituted starting materials afforded products in similar enantioselectivities (Scheme 2, 3f-h). However, the reaction was slower with the sterically more hindered ortho-chloro substrate (Scheme 2, 3f). When instead of a benzylidene-containing substrate an alkylidene with an extra ester moiety was used, the enantioselectivity was lost and the product $\mathbf{3 i}$ was obtained as a racemic mixture. Either additional coordination with the catalyst or a lack of $\pi-\pi$-interaction may have been responsible for that. Also, a higher $\mathrm{C}-\mathrm{H}$ acidity of the proton at the stereogenic centre and possible racemisation can't be excluded. A heteroaromatic oxindole derivative afforded the product $\mathbf{3 j}$ in lower yield and high ee values. 4- and 5-bromo oxindole derivatives (2l and $\mathbf{2 k}$, respectively) were also used as starting compounds. If the substituent in the oxindole ring was further from the reaction centre, the outcome was not affected (Scheme 2, 3k). However, when using a 4-bromo-substituted oxindole, the reaction was slower, the yield drastically decreased and the en- 


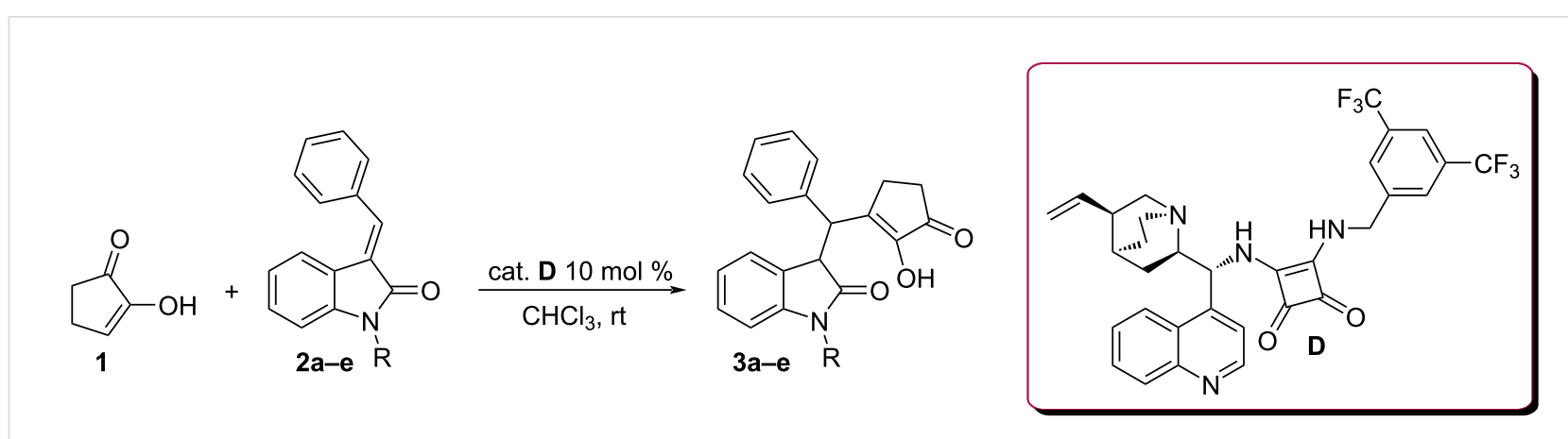

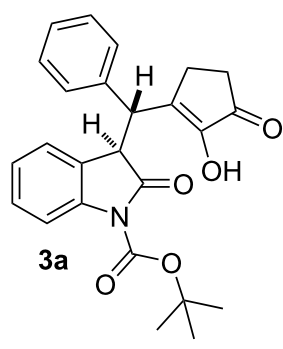

$$
\begin{aligned}
& 2 \mathrm{~h}, 75 \% \text { yield } \\
& \text { dr } 2.6: 1 \\
& \text { ee } 90 \% / 94 \%
\end{aligned}
$$

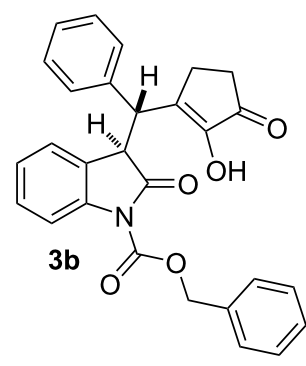

$2 \mathrm{~h}, 70 \%$ yield
$\mathrm{dr} 2.9: 1$ dr $2.9: 1$
ee $82 \% / 88 \%$

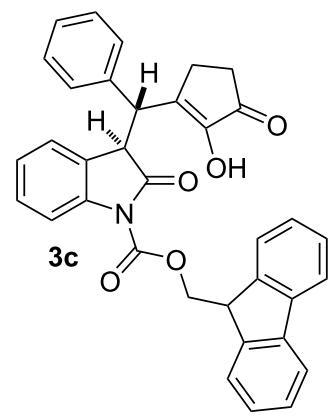

$1 \mathrm{~h}, 52 \%$ yield dr nd ee $82 \% / 82 \%$<smiles>O=C1CCC(C(c2ccccc2)C2C(=O)N(Cc3ccccc3)c3ccccc32)=C1O</smiles>

no reaction<smiles>Cc1ccc(S(=O)(=O)N2C(=O)[C@H]([C@H](C3=C(O)C(=O)CC3)c3ccccc3)c3ccccc32)cc1</smiles>

1 day, $42 \%$ yield

dr 2.1:1

ee nd

Scheme 1: Screening of different $N$-protecting groups. Reaction conditions: 0.2 M solution of 1 (1 equiv), 2 ( 1 equiv), of catalyst $\mathbf{D}$ ( 0.1 equiv), chloroform, at room temperature; isolated yields after column chromatography; ee determined by chiral HPLC.

antioselectivity was moderate (Scheme $2,3 \mathbf{3}$ ). The reaction with an electron-donating $p$-MeO-substituted benzylidene oxindole was very sluggish and did not reach full conversion (Scheme 2 , $3 \mathbf{m})$. The product $\mathbf{3 m}$ was obtained with only $36 \%$ yield and with undetermined enantiomeric purity, since the peaks were not separable in various HPLC methods. Similarly, the $p$-Mesubstituted oxindole was also slow in reacting and the yield was moderate, but the enantioselectivity remained high (Scheme 2, 3n). The reaction tolerated alkylidene oxindoles, although the product was obtained in a slightly lower yield and enantioselectivity (Scheme 2, 3o). The reaction did not occur when starting compound $\mathbf{2 p}$ was tried. This was probably because of the very poor solubility of the starting material. Generally, the diastereoselectivities of the reactions were moderate (dr 2.1:1-3.6:1) throughout the scope. The diastereoselectivity was missing or was very low for the compounds with non-aromatic substituents at the double bond (3i and $\mathbf{3 o})$.

The relative anti-configuration of the vicinal diastereotopic hydrogens was determined by comparing the ${ }^{3} J_{\mathrm{HH}}$ coupling constants of the major diastereomer with those of the minor diastereomer. The constants were larger for the major diastereomer, meaning vicinal hydrogens were in anti-configuration.
In all previous experiments only $E$-isomers were used. In the case of the 3-nitro-substituted starting material $\mathbf{2 q}$ we managed to separate isomers and carried out the reaction with both the $E$ and $Z$-isomer. In these experiments, both isomers afforded the same major diastereoisomer but opposite enantiomers (Scheme 3, 3q). The diastereoselectivities were similar for the isomers.

Since the diastereoselectivity of the reaction was low, we attempted to increase the ratio of diastereoisomers via enolisation followed by diastereoselective protonation (Table 2). As the racemate of $\mathbf{3 a}$ was obtained in a higher diastereomeric ratio (6.3:1) we applied kinetic and thermodynamic conditions for the epimerisation of it (Table 2, entries 1 and 2, respectively). Unfortunately, in both cases the diastereomeric ratio decreased and the amount of more stable syn diastereoisomer increased. A similar trend was observed when starting from the enantiomerically enriched 3a (Table 2, entry 3).

It has been shown that substituted oxindoles can be converted to indolopyrans via intramolecular cyclisation [33]. We also tried synthesizing $4 H$-pyrans in acidic conditions but no cyclised product was detected. 

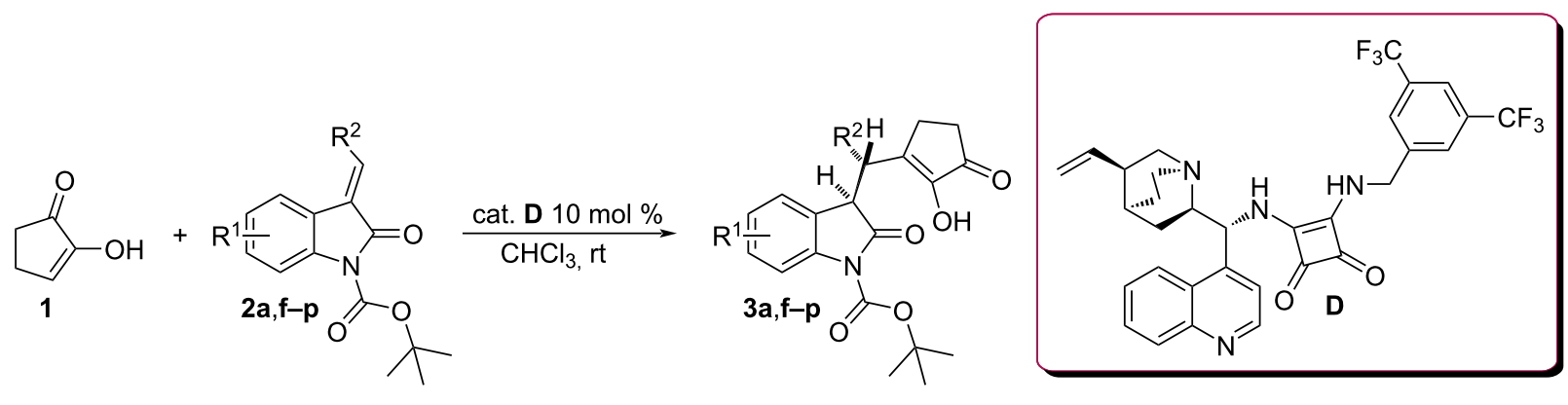
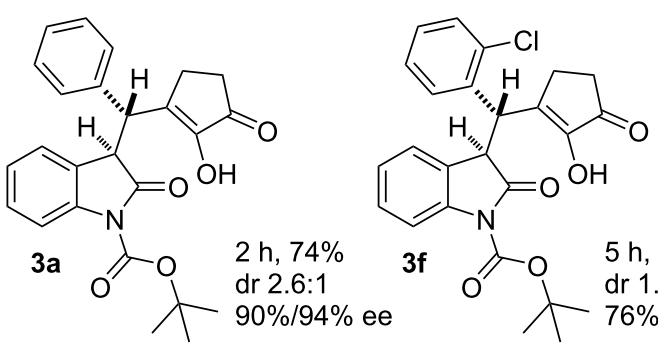

$3 \mathbf{f}$
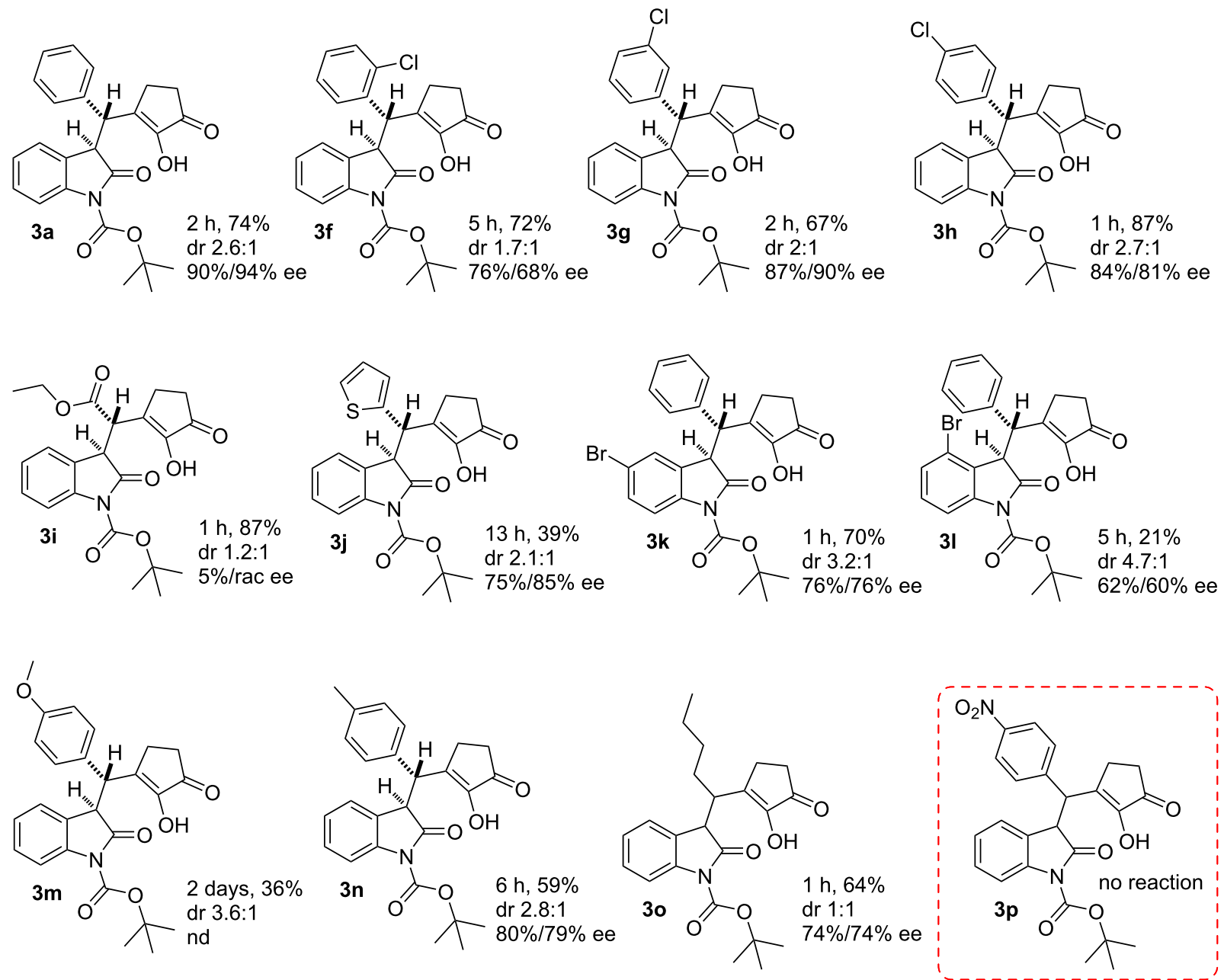

Scheme 2: Scope of the reaction (the relative configuration of the major diastereoisomer is depicted). Reaction conditions: $0.2 \mathrm{M}$ solution of 1 equiv of 1,2 equiv of $2,0.1$ equiv of catalyst $D$, chloroform, at room temperature; isolated yields after column chromatography; ee determined by chiral HPLC.

\section{Conclusion}

In summary, we have developed a new asymmetric organocatalytic Michael addition of cyclopentane-1,2-dione to alkylidene oxindoles catalysed by bifunctional squaramide which leads to products in high enantioselectivities and moderate diastereose- lectivities. The scope of alkylidene oxindoles is reasonably wide including aromatic and aliphatic substituents at the double bond and also substituents in the oxindole core. The work widens the synthetic utility of cyclopentane-1,2diones. 


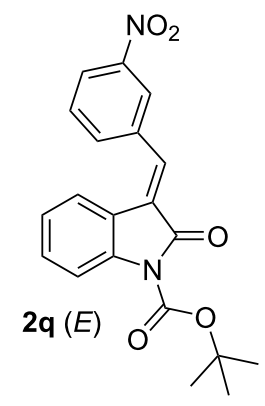<smiles>CC(C)(C)OC(=O)N1C(=O)/C(=C\c2cccc([N+](=O)[O-])c2)c2ccccc21</smiles><smiles></smiles><smiles>O=C1CCCC1O</smiles><smiles>C1CCCCC1</smiles>

cat. D $10 \mathrm{~mol} \%$
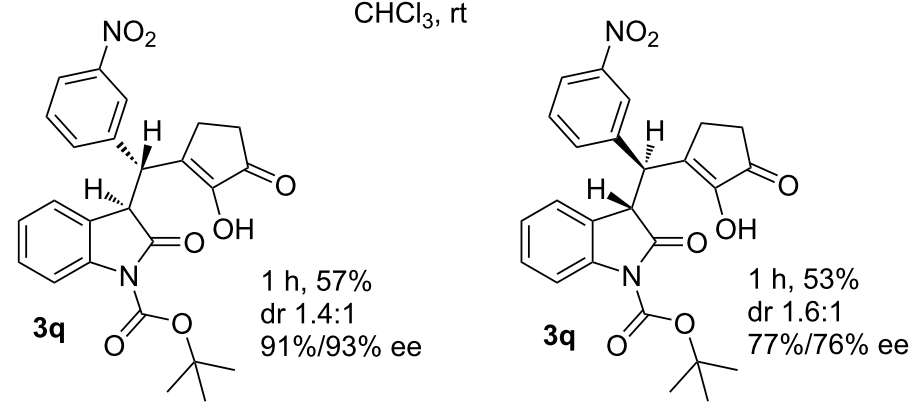

Scheme 3: Comparison reactions of $E$ - and $Z$-isomers (the relative configurations of the major diastereoisomers are depicted). Reaction conditions: $0.2 \mathrm{M}$ solution of 1 equiv of $\mathbf{1 , 2}$ equiv of $2,0.1$ equiv of catalyst $\mathbf{D}$, chloroform, at room temperature; isolated yields after column chromatography; ee determined by chiral HPLC.

Table 2: Epimerisation of 3a.

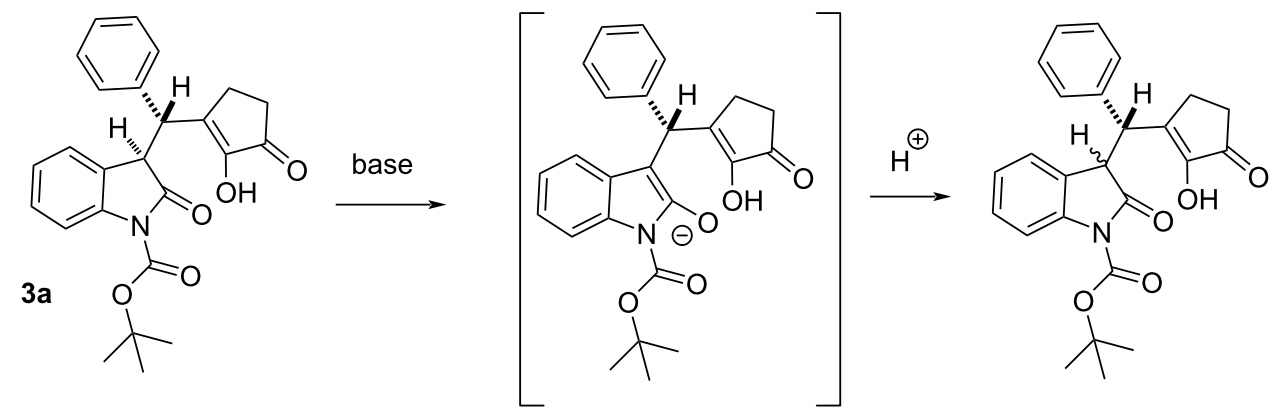

\begin{tabular}{|c|c|c|c|c|}
\hline \multirow[t]{2}{*}{ Entry } & \multicolumn{2}{|c|}{ Starting compound } & \multirow[t]{2}{*}{ Conditions } & \multirow{2}{*}{$\begin{array}{l}\text { Product } \\
\text { (dr) }\end{array}$} \\
\hline & & $\mathrm{dr}$ & & \\
\hline 1 & $3 \mathbf{a}(\mathrm{rac})$ & $6.3: 1$ & LDA, THF; $-78{ }^{\circ} \mathrm{C}, 30 \mathrm{~min}$, then sat. aq. $\mathrm{NH}_{4} \mathrm{Cl}$ & $2.7: 1$ \\
\hline 2 & $3 \mathbf{a}(\mathrm{rac})$ & $6.3: 1$ & $t$-BuOK/t-BuOH, rt, overnight & $2.6: 1$ \\
\hline 3 & $3 a$ & $2.5: 1$ & LiHDMS, THF; $-78{ }^{\circ} \mathrm{C}, 30 \mathrm{~min}$, then sat. aq. $\mathrm{NH}_{4} \mathrm{Cl}$ & $2.2: 1$ \\
\hline
\end{tabular}




\section{Supporting Information}

\section{Supporting Information File 1}

Experimental details, NMR spectra, HPLC chromatograms. [https://www.beilstein-journals.org/bjoc/content/ supplementary/1860-5397-18-18-S1.pdf]

\section{Funding}

The authors thank the Estonian Ministry of Education and Research (Grant No. PRG1031) and the Centre of Excellence in Molecular Cell Engineering (2014-2020.4.01.15-0013) for financial support.

\section{ORCID ${ }^{\circledR}$ iDs}

Ivar Järving - https://orcid.org/0000-0001-6047-4759

Tõnis Kanger - https://orcid.org/0000-0001-5339-9682

\section{References}

1. Sharma, D.; Kumar, M.; Das, P. Synth. Commun. 2021, 51, 2553-2573. doi:10.1080/00397911.2021.1946824

2. Shokova, E. A.; Kim, J. K.; Kovalev, V. V. Russ. J. Org. Chem. 2015, 51, 755-830. doi:10.1134/s1070428015060019

3. de Gonzalo, G.; Alcántara, A. R. Pharmaceuticals 2021, 14, 1043. doi:10.3390/ph14101043

4. Rueping, M.; Kuenkel, A.; Tato, F.; Bats, J. W. Angew. Chem., Int. Ed. 2009, 48, 3699-3702. doi:10.1002/anie.200900754

5. Rueping, M.; Volla, C. M. R.; Bolte, M.; Raabe, G. Adv. Synth. Catal. 2011, 353, 2853-2859. doi:10.1002/adsc.201100258

6. Nair, D. K.; Menna-Barreto, R. F. S.; da Silva Júnior, E. N.; Mobin, S. M.; Namboothiri, I. N. N. Chem. Commun. 2014, 50, 6973-6976. doi:10.1039/c4cc02279c

7. Ramireddy, N.; Abbaraju, S.; Ding, D.; Arman, H.; Zhao, J. C.-G. J. Heterocycl. Chem. 2017, 54, 677-691. doi:10.1002/jhet.2641

8. El-Sepelgy, O.; Haseloff, S.; Alamsetti, S. K.; Schneider, C. Angew. Chem., Int. Ed. 2014, 53, 7923-7927. doi:10.1002/anie.201403573

9. Xian, J.; Chen, L.; Ye, L.; Sun, Y.; Shi, Z.; Zhao, Z.; Li, X. Tetrahedron 2019, 75, 2350-2356. doi:10.1016/j.tet.2019.03.007

10. Gao, Y.-Q.; Hou, Y.; Chen, J.; Zhen, Y.; Xu, D.; Zhang, H.; Wei, H.; Xie, W. Org. Biomol. Chem. 2021, 19, 348-354. doi:10.1039/d0ob02140g

11. Staunton, J.; Wilkinson, B. Chem. Rev. 1997, 97, 2611-2630. doi:10.1021/cr9600316

12. Mosnáček, J.; Weiss, R. G.; Lukáč, I. Macromolecules 2004, 37, 1304-1311. doi:10.1021/ma030213j

13. Wolkenberg, S. E.; Wisnoski, D. D.; Leister, W. H.; Wang, Y.; Zhao, Z.; Lindsley, C. W. Org. Lett. 2004, 6, 1453-1456. doi:10.1021/ol049682b

14. Deng, X.; Mani, N. S. Org. Lett. 2006, 8, 269-272. doi:10.1021/ol052663x

15. Herrera, A. J.; Rondón, M.; Suárez, E. J. Org. Chem. 2008, 73 3384-3391. doi:10.1021/jo702663w

16. Ding, D.; Zhao, C.-G. Tetrahedron Lett. 2010, 51, 1322-1325. doi:10.1016/j.tetlet.2009.12.139
17. Rueping, M.; Kuenkel, A.; Fröhlich, R. Chem. - Eur. J. 2010, 16, 4173-4176. doi:10.1002/chem.201000237

18. Ren, Q.; Li, M.; Yuan, L. Org. Biomol. Chem. 2017, 15, 1329-1333. doi:10.1039/c6ob02449a

19. Paju, A.; Kanger, T.; Pehk, T.; Eek, M.; Lopp, M. Tetrahedron 2004, 60, 9081-9084. doi:10.1016/j.tet.2004.07.096

20. Paju, A.; Kostomarova, D.; Matkevitš, K.; Laos, M.; Pehk, T.; Kanger, T.; Lopp, M. Tetrahedron 2015, 71, 9313-9320. doi:10.1016/j.tet.2015.10.014

21. Jõgi, A.; Paju, A.; Pehk, T.; Kailas, T.; Müürisepp, A.-M.; Lopp, M. Tetrahedron 2009, 65, 2959-2965. doi:10.1016/j.tet.2009.02.010

22. Preegel, G.; Noole, A.; Ilmarinen, K.; Järving, I.; Kanger, T.; Pehk, T.; Lopp, M. Synthesis 2014, 46, 2595-2600. doi:10.1055/s-0034-1378374

23. Preegel, G.; Ilmarinen, K.; Järving, I.; Kanger, T.; Pehk, T.; Lopp, M. Synthesis 2015, 47, 3805-3812. doi:10.1055/s-0035-1560347

24. Preegel, G.; Silm, E.; Kaabel, S.; Järving, I.; Rissanen, K.; Lopp, M. Synthesis 2017, 49, 3118-3125. doi:10.1055/s-0036-1588787

25. Silm, E.; Kaabel, S.; Järving, I.; Kanger, T. Synthesis 2019, 51, 4198-4204. doi:10.1055/s-0039-1690484

26. Fang, X.; Wang, C.-J. Chem. Commun. 2015, 51, 1185-1197. doi:10.1039/c4cc07909d

27. Okino, T.; Hoashi, Y.; Takemoto, Y. J. Am. Chem. Soc. 2003, 125 12672-12673. doi:10.1021/ja036972z

28. Zhao, B.-L.; Li, J.-H.; Du, D.-M. Chem. Rec. 2017, 17, 994-1018. doi:10.1002/tcr.201600140

29. Hamza, A.; Schubert, G.; Soós, T.; Pápai, I. J. Am. Chem. Soc. 2006, 128, 13151-13160. doi:10.1021/ja063201x

30. Izzo, J. A.; Myshchuk, Y.; Hirschi, J. S.; Vetticatt, M. J. Org. Biomol. Chem. 2019, 17, 3934-3939. doi:10.1039/c9ob00072k

31. Zhang, Z.; Schreiner, P. R. Chem. Soc. Rev. 2009, 38, 1187-1198. doi:10.1039/b801793j

32. Brak, K.; Jacobsen, E. N. Angew. Chem., Int. Ed. 2013, 52, 534-561. doi:10.1002/anie.201205449

33. Bartsch, H.; Eiden, F.; Buchborn, H. Arch. Pharm. (Weinheim, Ger.) 1982, 315, 481-490. doi:10.1002/ardp.19823150602

\section{License and Terms}

This is an open access article licensed under the terms of the Beilstein-Institut Open Access License Agreement (https://www.beilstein-journals.org/bjoc/terms), which is identical to the Creative Commons Attribution 4.0 International License (https://creativecommons.org/licenses/by/4.0). The reuse of material under this license requires that the author(s), source and license are credited. Third-party material in this article could be subject to other licenses (typically indicated in the credit line), and in this case, users are required to obtain permission from the license holder to reuse the material.

The definitive version of this article is the electronic one which can be found at: $\underline{\text { https://doi.org/10.3762/bjoc.18.18 }}$ 